\title{
Heterosis Studies for Growth and Yield Traits in Tomato (Solanum lycopersicum L.)
}

\author{
Suresh Kumar Sah*, Anand Kumar Singh, B.K. Singh, \\ Kalyan Barman, A.K. Pal and Ashutosh Kumar
}

Department of Horticulture, Institute of Agricultural Sciences, BHU, Varanasi, India

*Corresponding author

\begin{tabular}{|l|}
\hline \multicolumn{1}{l|}{} \\
\hline Key w o r d s \\
Standard heterosis, \\
Hybrids, Check, \\
Yield characters, \\
Fruit yield/plant \\
\hline Article Info \\
\hline $\begin{array}{l}\text { Accepted: } \\
\text { 20 September } 2020 \\
\text { Available Online: } \\
\text { 10 October } 2020\end{array}$ \\
\hline
\end{tabular}

\section{A B S T R A C T}

Standard heterosis over one check (DVRT-1) was experimented with thirty hybrids of tomato. Most of these hybrids proved to have unique variation for growth and yield traits in tomato. Standard heterosis over check for total yield/plant was recorded $99.76 \%$. Highest Heterosis variation was fund to be in number of primary branches/plant, followed by average fruit weight, fruit yield (q/ha), number of fruits/plant, number of fruits / cluster. The statistically 'highest significant positive standard heterosis for fruit yield $(\mathrm{q} / \mathrm{ha}$ ) was recorded in hybrid EC-570028 × EC-520061(99.76\%.), followed by hybrids EC-552141 × EC$520061(96.57 \%)$ and EC-552141 $\times$ Hisar Arun (96.43\%). The hybridEC$620500 \times$ Hisar Arun (-29.82 \%) found to have the "statistically highest significant positive standard heterosis" for days to $50 \%$ flowering, followed by hybridsEC$538405 \times$ EC-520061 (-13.06 \%) and EC-538405 × Hisar Arun (-16.26). Thus these hybrids can be utilized by breeders for developing early flowering, maturing and fruiting types of tomato varieties. Thus from this experimentation we concluded that for the development of commercially high yielding tomato hybrids the breeder should include or select parents with high desirable genetic variability.

\section{Introduction}

Tomato (Lycopersicon esculentum Mill) is a widely cultivated vegetable crop which is a diploid species with $2 \mathrm{n}=2 \mathrm{x}=24$ chromosomes. Peru-Ecuador is considered to be the centre of origin of tomato (Rick, 1976), it is introduced by Portuguese in India during era colonization. Tomato is the world's second most consumed vegetable after potato
(Foolad, 2007). The total world production of tomato is 161.7 million metric tons with a value of $\sim \$ 59$ billion. USA tomato production contributes 13.2 million metric tons with a value of $\$ 5$ billion to the total world production. The India ranks in second position in the total world production of tomato after China (Anonymous, 2017). Heterosis breeding is an useful instrument for varietal upgradation of tomato as 
recommended by different researchers like Bhatt et al., 1999; Premalakshme et al., 2005; Fageria et al., 2001; Thakur et al., 2004; Duhan et al., 2005. Though tomato is a selfpollinated crop, the unusual high heterosis observed in tomato proved to be highly outcrossing genus and has later evolved into a self-pollinated one(Rick, 1976). "Line $\times$ Tester" method can evaluate relatively more number of genotypes or lines in less time as compared to diallel and partial diallel crosses (Garg et al., 2008). For estimating genetic component of variability the method used by (Haydar et al., 2007) was practiced. In this study efforts have been done to identify parents suitable for tomato hybrid seed production.

\section{Materials and Methods}

This experiment were conducted during three Rabi Seasons 2015-2016, 2016-2017, and 2017-2018 at Vegetable Research Farm, Department of Horticulture, Institute of Agricultural Sciences, Banaras Hindu University, Varanasi, India. Located in the middle Gangetic plain (latitude: 25019'59', longitude: 83000'00' EN elevation above sea level: $77 \mathrm{~m}$ ) in the eastern part of the state of Uttar Pradesh. It is located in the IndoGangetic Plains of North India. The experimental material for this study comprised often lines as female and three testers as male which were selected based on their perse performance for various traits. Thirty cross combinations were obtained in a Line $\times$ Tester (Kempthorne, 1957) mating design. DVRT-1 was used as check. The parents were provided by ICAR, Indian Institute of Vegetable Research (IIVR), Varanasi, UP, India. The experimental material comprised ten genetically diverse lines (EC-620421, EC-620536, EC-620494, EC-620500, EC-620520, EC-620502, EC552141, EC-538405, EC-570028 and EC273966). Three testers (EC-520061, EC-
520058, and Hisar Arun) along with their thirty $\mathrm{F}_{1} \mathrm{~s}$ developed by crossing them in a line $\times$ tester mating design (Kempthorne, 1957) and one check. During Rabi: 2015-16 ten elite lines and three testers of tomatoes were planted for producing $F_{1}$ by crossing in line $\times$ tester fashion. A total of $30(10 \times 3)$ crosses were made. Individual plants of parents were selfed to maintain pure seed. Again during Rabi:2016-17 thirty $\mathrm{F}_{1} \mathrm{~s}$ and thirteen parents along with one check were raised in RBD in three replications and population size was thirty plants per treatment with standard spacing at Vegetable Research Farm, Department of Horticulture, Institute of Agricultural Sciences, Banaras Hindu university, Varanasi, UP, India. Data were recorded on yield and quality traits. FreshF $\mathrm{F}_{1} \mathrm{~S}$ were obtained by crossing ten elite lines and three testers of tomato. During Rabi season of 2017-18 thirty $\mathrm{F}_{1} \mathrm{~s}$, and thirteen parents along with one check were raised. Parents, $F_{1 S}$ were grown in RBD in three replications to study combining ability, heterosis and gene action for growth and yield characters. All the inter cultural operations were performed as and when required. The observations were recorded for nine different characters i.e. Plant height $(\mathrm{cm})$, Day to $50 \%$ flowering, Number of primary branches per plant, Number of fruits per cluster, Average fruit weight $(\mathrm{g})$, Fruit length $(\mathrm{cm})$, Fruit width $(\mathrm{cm})$, Number of fruits per plant, Fruit yield (q/ha).

For design of experiment, analysis of variance was carried out following Panse and Sukhatme (1967). The significance of differences among treatment means (parent and crosses)was tested by 'F-test'. For assessment of general and specific combining ability variances and their effects, the" line×tester' analysis was carried out following method given by Kempthorne (1957) and elaborated by Arunachalam (1974). Linextester analysis was used on a limited scale to determine GCA and SCA of different 
lines. It is analogous to "North Carolina Design II" (Comstock and Robinson, 1952). In this design, a random sample of ' $l$ ' lines is taken and each line is mated to each of the ' $t$ ' testers (Singh and Chaudhary, 1977). Heterosis in $F_{1}$ 's will be calculated as the difference of $F_{1}$ cross performance from the check (Standard heterosis) and better parent (heterobeltiosis) by using the formulae (Kempthorne, 1957). The nature and magnitude of heterosis was computed as percentage increase or decrease of the mean values of cross $\left(\mathrm{F}_{1}\right.$ 's) over better parent $(\mathrm{BP})$ and the standard check (SC). Significance of heterosis was tested following the ' $t$ ' test. The calculated ' $t$ ' value was compared with table value of ' $\mathrm{t}$ ' at error degree of freedom from ANOVA comprising parents and $\mathrm{F}_{1} \mathrm{~s} \mathrm{P}=0.05$ and $\mathrm{P}=0.01$.

\section{Results and Discussion}

The source of variation showed highly significant and significant differences for most of the yield and quality traits. The analysis of variance indicated highly significant differences with respect to general combining ability of parents for days to $50 \%$ flowering'; number of fruits' percluster, number of branches' per plant, pericarp' thickness $(\mathrm{mm})$, fruit weight $(\mathrm{g})$, fruit yield (q/ha),fruit length $(\mathrm{cm})$, fruit width $(\mathrm{cm})$, number of fruits per plant for standard heterosis over check. Nine different characters in tomato for superior three hybrids are presented in table no.1. The highest significant standard heterosis over the check was exhibited byhybrid EC-273966 × EC$520058(19.43 \%)$. This proves the presence of both non-additive gene effect and additive gene effects in these hybrids for plant height. Similar finding were reported by Harer et al., (2006); Sharmaand Thakur (2008); Mehta and Asati (2008); Kumar et al., (2016), Pattnaik et al., (2020a); and Pattnaik et al., (2020b). Earliness in days to 50per cent flowering and days to $50 \%$ fruit setting is one of the important components to develop early maturing tomato hybrid variety. Hybrid EC$620500 \times$ Hisar Arun expressed highest significant negative heterosis over check parent (-29.82\%). This was good general combiner for early maturity. Negative heterosis for days to first flowering was also reported by Singh and Singh (1993); Kulkarni (2003); Mahendrakar (2004); Duhan et al., (2005); and Premalakshme et al., (2005) over the better parent in many of the cross combinations in their diallel progenies. Statically "maximum significant heterosis over the check" was found to be in hybridEC$570028 \times$ EC-520058 (251.93 \%).It suggesting the requirement of non-additive gene action. Patil (2003), Duhan et al., (2005) and Ramezan et al., (2009) also reported same result. Number of fruits per cluster was proved to be the highest over the check parent in hybrid EC-620494 $\times$ Hisar Arun (80.93 \%). This result is in accordance with the observation of Sharma and Thakur (2008), Kumari and Sharma (2011) and Kumar et al., (2012). Average fruit weight was expressed maximum over the check parent by the hybrid EC-273966 × EC-520061 (209.53 \%). Average fruit weight is one of the most necessary yield characters for breeding high yielding tomato varieties. Four cross combinations showed significantly useful heterobeltiosis for average fruit weight which was observed by Gul (2010). Positive heterosis over better parent for average fruit weight was also reported by Hussain et al., (2001) and Singh et al., (2005). In the present investigation the yield $\mathrm{q} / \mathrm{ha}$ increased mainly due to increase in average fruit weight and number of fruits per plant.

Statically highest significant standard heterosis for fruit length was expressed by hybrid EC-552141 × Hisar Arun (56.18 \%) over check parent. 
Table.1 Heterosis over standard check for growth and yield (DVRT-1) of different characters in tomato

\begin{tabular}{|c|c|c|c|}
\hline \multirow[t]{2}{*}{ S.NO } & \multirow[t]{2}{*}{ Character } & \multicolumn{2}{|c|}{ Standard heterosis over check } \\
\hline & & Superior hybrids & $(\%)$ \\
\hline \multirow[t]{3}{*}{1.} & \multirow{3}{*}{ Plant height $(\mathrm{cm})$} & EC-273966 × EC-520058 & 19.43 \\
\hline & & EC-620536 × EC-520058 & 16.27 \\
\hline & & EC-620520 × EC-520058 & 15.78 \\
\hline \multirow[t]{3}{*}{2.} & \multirow[t]{3}{*}{ Daysto50 \% flowering } & EC- $620500 \times$ Hisar Arun & -29.82 \\
\hline & & EC-538405×EC-520061 & -13.06 \\
\hline & & EC-538405 $\times$ Hisar Arun & -16.26 \\
\hline \multirow[t]{3}{*}{3.} & \multirow{3}{*}{$\begin{array}{l}\text { Number of primary branches } \\
\text { per plant }\end{array}$} & EC-570028 × EC-520058 & 251.93 \\
\hline & & EC-570028 $\times$ Hisar Arun & 250.80 \\
\hline & & EC-570028 × EC-520061 & 187.73 \\
\hline \multirow[t]{3}{*}{4.} & \multirow[t]{3}{*}{ Number of fruits per cluster } & EC-620494 × Hisar Arun & 80.93 \\
\hline & & EC-552141 × Hisar Arun & 75.90 \\
\hline & & EC-620500 $\times$ Hisar Arun & 75.34 \\
\hline \multirow[t]{3}{*}{5.} & \multirow[t]{3}{*}{ Average fruit weight } & EC-273966 × EC-520061 & 209.53 \\
\hline & & EC-570028 × EC-520061 & 195.45 \\
\hline & & EC-538405 $\times$ Hisar Arun & 195.18 \\
\hline \multirow[t]{3}{*}{6.} & \multirow[t]{3}{*}{ Fruit length $(\mathrm{cm})$} & EC-552141 $\times$ Hisar Arun & 56.18 \\
\hline & & EC-570028 $\times$ Hisar Arun & 55.25 \\
\hline & & EC-552141 × EC-520061 & 45.69 \\
\hline \multirow[t]{3}{*}{7.} & \multirow[t]{3}{*}{ Fruit width $(\mathrm{cm})$} & EC-620421 × EC-520058 & 23.94 \\
\hline & & EC-620494 × EC-520061 & 23.70 \\
\hline & & EC-620500 $\times$ Hisar Arun & 22.87 \\
\hline \multirow[t]{3}{*}{8.} & \multirow[t]{3}{*}{ Number of fruits per plant } & EC-620421 $\times$ Hisar Arun & 84.85 \\
\hline & & EC-620520 × EC-520058 & 78.51 \\
\hline & & EC-552141 × EC-520058 & 77.29 \\
\hline \multirow[t]{3}{*}{9.} & \multirow[t]{3}{*}{ Fruit yield (q/ha) } & EC-570028 × EC-520061 & 99.76 \\
\hline & & EC-552141 × EC-520061 & 96.57 \\
\hline & & EC-552141 $\times$ Hisar Arun & 96.43 \\
\hline
\end{tabular}


Fruit length is one of the most necessary characters for breeding big size tomato for commercial purpose. Fruit width was observed maximum in the hybrid EC-620421 $\times$ EC-520058 (23.94\%). Fruit width is one of the most important characters for breeding big size tomato for commercial purpose. These results are in line with the reports from, Islam et al., (2012) and Aisyah et al., (2016). The hybridEC-620421 × Hisar Arun showed statistically "highest significant standard heterosis" for number of fruits per plant over check parent. Major yield contributing character is the number of fruits per plant. These results are online with Prashant (2004); Kulkarni (2003); Joshi and Thakur (2003); and Sharma and Thakur (2008). Significant result has been also found for number of fruits per plant by Saleem et al., (2009). These results are also on line with the results of Mirshamssi et al., (2006); Rani and Veeraragavathatham (2008); Kumar et al., (2016b), Pattnaik et al., (2020a); and Pattnaik et al., (2020b). Fruit yield was recorded statistically "significant maximum standard heterosis" in hybrid EC-570028 × EC520061(99.76 \%) over check parent. Similar results were also reported by Wagh et al., (2004); Harer et al., (2006); and Sharma and Thakur (2008). Yield is a composite character, evidences suggest that heterosis of such a compound character is much regulated by the vigour expressed by its component character (Sinha and Khanna, 1975) such as average fruit weight, no. of number of fruits' per plant, fruits per' cluster, and fruit yield $\mathrm{q} / \mathrm{ha}$. These findings were similar with the findings of Kulkarni (2003); Prashant (2004); Kumar et al., (2013); Kumar et al., (2016 b), Pattnaik et al., (2020a); and Pattnaik et al., (2020b).

\section{References}

Anonymous, FAOSTAT Database.2017. Available

online, http//faostat.org/site/339/default. aspx., accessed on 19 September.

Arunachalam, V.C. 1974. The fallacy behind the use of a modified line tester design, Indian J. of Genet., 34, 280- 287.

Aisyah, S.I., Wahyuni, S., Syukur, M. and Witono, J.R.2016. The estimation of combining ability and heterosis effect for yield and yield components in tomato (Solanum lycopersicum Mill.) at Lowland, Ekin Journal of Crop Breeding and Genetics 2 (1): 23-29.

Bhatt, R.P., Biswas, V.R., Narendra, K. and Kumar, N.1999. Studies of heterosis for certain characters in tomato (Lycopersicon esculentum L.) under mid hill condition, Prog. Hort, 31(1-2), 41-43.

Comstock, R.E. and H.F. Robinson.1952. Genetic parameters, their estimation and significance, Proceedings of the 6th Inter. Grassland Congress, 1.

Duhan, D., Partap, P.S., Rana, M.K. and Dahiya, M.S. 2005.Heterosis study for quality characters in a line $x$ tester set of tomato, Haryana J. Hort. Sci., 34, 371375.

Fageria, M.S., Kohli, U.K. and Dhaka, R.S. 2001. Studies on heterobeltiosis for fruit yield and yield attributing traits in tomato, Haryana J. Hort. Sci., 30(1-2), 131-133.

Foolad, M.R.2007.Genome mapping and molecular breeding of tomato, Int. J. Pl. Geno., 64358.

Garg, N., Cheema D.S. and Dhatt, A.S.2008. Genetics of yield, quality and shelf life characteristics in tomato under normal and late planting conditions, Euphytica, $159,275-288$.

Gul, R. Hidayat-Ur-Rahman, Khalil, I H., Shah, S.M.A. and Ghafoor, A. 2010. Heterosis for flower and fruit traits in tomato (Lycopersicon esculentum Mill.), African J. Biotech., 9(27), 41444151. 
Harer, P.N., Kulkarni, R.V. and Deeptashri, B.2006.Heterosis for yield components, TSS and ascorbic acid contents in tomato (Lycopersicon esculentum Mill). Crop Res., 7(1), 270-274.

Haydar, A., Mandal, A.M., Ahmed, M.B., Hannan, M.M., Karim, R., Razvy, M.A., Roy, U.B. and Salahin, M. 2007.Studies on genetic variability and interrelationship among the different traits in tomato (Lycopersicon esculentum Mill.), Middle-East J. Sci. Res., 2(3-4), 139-142.

Hussain, S.I., Khokhar, K.M. Laghari, M.H. and Mahmud, M.M. 2001. Yield potential of some exotic and one local tomato cultivars grown for summer production, Pak. J. Biol. Sci., 4,12151216.

Islam, M.R., Ahmad, S. and Rahman, M. 2012.Heterosis and Qualitativeattributes in Winter Tomato Solanum lycopersicum L.) Hybrids Bangladesh Journal Agricultural Research. 37(1): $39-48$.

Joshi, A., and Thakur, M.C. 2003. Exploitation of heterosis for yield and yield contributing traits in tomato (Lycopersicon esculentum Mill.), Prog. Hort., 35, 64-68.

Kempthorne, O. 1957. An Introduction to genetic statistics, New York, John Wiley and sons, Inc; London Chapman \& Hall, Ltd.

Kulkarni, G.P.2003. Investigations on bacterial wilt resistance in tomato, Ph.D. Thesis, Univ. Agric. Sci., Dharwad (India).

Kumar, P., Singh, A.K., Rai, N. K. and Singh, B.K. 2016a.Magnitude of heterosis in interspecific $\mathrm{F}_{1}$,s for ToLCV, earliness, yield and quality traits in tomato (Solanum lycopersicon L.). Bioved, 27(2): 365-374.

Kumar, S., and Gowda P.H.2016b. Estimation of heterosis and combining ability in tomato for fruit shelf life and yield component traits using line $\mathrm{x}$ tester method, Int. J. Env. Agric. Res. 2(3), 455-470.

Kumar, V., Nandan, R., Sharma, S.K., Srivastava, K., Kumar, R. and Singh, M.K.2013. Heterosis study for quality attributing traits in different crosses in tomato (Solanum lycopersicum LS.), P1. Archives, 13(1), 21-26.

Kumar, V., Nandan, R., Srivastava, K., Sharma, S.K., Kumar, R. and Kumar, A.2012. Genetic parameters and correlation study for yield and quality traits in tomato, Asian J. Hort., 7(2), 454-459.

Kumari, S. and Sharma, M. K.2011. Exploitation of heterosis for yield and its contributing traits in tomato (Solanum lycopersicum L.), Int. J. Farm Sci., 1(2), 45-55.

Mahendrakar, P. 2004. Development of $F_{1}$ crosses in tomato (Lycopersicon esculentum Mill.), Uni. Agric. Sci., Dharwad (India).

Mehta, N. and Asati, B.S.2008.Genetic relationship of growth and development trait with fruit yield in Tomato (Lycopercon esculentum Mill.) Karnataka, J. Agric. Sci., 21(1), 92-96.

Mirshamssi, A, Farsi, M., Shahriari, F. and Nemati, H. 2006. Estimation of heterosis and combining ability for yield components and crossing method, Agric. Sci. Tech., 20(3), 3-12.

Panse, V.G. and Sukhatme, P.V.1967. Statistical Methods for Agricultural Workers, ICAR Publication, 381.

Pattnaik, P., Singh, A.K., Kumar, B., Mishra, D. and Singh, B.K.2020a. Studies on the Effect of Heterosis for Yield and Yield contributing plant Traits in Tomato (Solanum lycopersicum L.). International Journal of Current Microbiology and Applied Science. 9(4): 97-104. 
Pattnaik, P., Singh, A.K., Kumar, B., Mishra, D. Singh, B.K. Barman, K and Pal, A.K. 2020b.Analysis of heterotic pattern of $\mathrm{F}_{1}$ 's in Tomato (Solanum lycopersicum L.) for the improvement of yield and quality traits. International Journal of Chemical Studies. 8(4): 3160-3165.

Patil, V.S. 2003. Studies on double crosses involving potential tomato crosses. $\mathrm{M}$. Sc. (Agri.) Thesis, Univ. Agric. Sci., Dharwad (India).

Prashant, H. 2004. Heterosis and combining ability analysis for higher lycopene content in tomato. M.Sc. (Agri.) Thesis, Univ. Agric. Sci., Dharwad (India).

Premalakshme, V., Thangaraj, T.2005. Veeraragavathatham and Arumugam, T., Heterosis and combining ability in tomato, Veg. Sci., 32(1), 47-50.

Ramezan, A., Nejad, K., Najafi, F. and Tofighi, C.2009. Diverse responses of tomato to $\mathrm{N}$ and $\mathrm{P}$ deficiency, Int. $\mathrm{J}$. Agric. Biol., 11, 209-213.

Rani, C.I. and Veeraragavathatham, D. 2008. Studies on heterosis in root knot nematode (Meloidogyne incognita) resistant crosses in tomato (Lycopersicon esculentum Mill), Asian J. Hort., 3(1), 40-44.

Rick, C.M.1976. Tomato, evaluation of crop plant, Longman, London, 276-286.

Saleem, M.Y., Asghar, M., Haq, M.A., Rafique, T., Kamran, A. and Khan, A.A. 2009. Genetic analysis to identify suitable parents for cross seed production in tomato (Lycpersicon esculentum Mill.), Pak. J. Bot., 41(3), 1107-1116.

Sharma, D. and Thakur, M.C.2008. Evaluation of diallel progenies for yield and its contributing traits in tomato under mid hill condition, Indian J. Hort. 65(3), 297-301.

Singh, A., Gautam, J.P.S., Upadhyay, M. and Joshi, A. 2005. Heterosis for yield and quality characters in tomato, Crop Res., 29(2), 285-7.

Singh, R.K. and Singh V.K.1993. Heterosis breeding in tomato (Lycopersicon esculentum Mill.), Ann. Agric. Res., 14(4), 416-420.

Singh, R.K. and Chaudhary, B.D, (Ed.). 1977. Variance and covariance analysis. In, Biometrical methods in quantitative genetic analysis. Revised Ed. Kalyani, Ludhiana, Pp. 39-69.

Sinha, S.K. and Khanna, R.1975. Physiological, biochemical and genetic basis of heterosis, Ad. in Agro., 27, 123-174.

Thakur, A.K., Kohli, U.K. and Joshi, A. 2004.Evaluation of diallel progeny and heterosis for yield and yield contributing components in tomato, Haryana J. Hort. Sci., 33(1-2), 106-108.

Wagh, R.S., Bharud, R.W. and More, S.R.2004. Stability differences among tomato genotypes for yield and yield attributes, Ann. Pl. Physiol., 18, 176181.

\section{How to cite this article:}

Suresh Kumar Sah, Anand Kumar Singh, B.K. Singh, Kalyan Barman, A.K. Pal and Ashutosh Kumar. 2020. Heterosis Studies for Growth and Yield Traits in Tomato (Solanum lycopersicum L.). Int.J.Curr.Microbiol.App.Sci. 9(10): 2732-2738. doi: https://doi.org/10.20546/ijcmas.2020.910.330 